\title{
Observations on the Boron-Manganese Relationships in Soybean and Corn Plants
}

\author{
E. Hernández-Medina and M. A. Lugo-López ${ }^{1}$
}

IN'TRODUC'TION

Manganese-toxicity chlorosis of pineapple has been reported in Puerto Rico. Such toxicity may result from the high-soluble manganese and lowsoluble iron contents of substrates (3)..$^{2}$ Schapelle (5) studied the effect of trace elements on the growth and development of pineapples, emphasizing the cause and prevention of chlorosis. $\mathrm{H}$ is studies indicated that aluminum and boron seemed to prevent the manganese-induced chlorosis, probably by rendering the iron more available for normal chlorophyl synthesis.

In an attempt to obtain more information on the possible corrective effect of boron on manganese-induced chlorosis, experiments were conducted at Río Piedras under greenhouse conditions, using soybeans and corn as indicator plants.

\section{EXPERIMENTAL PROCEDURE}

SOYBEAN EXPERIMENT

Seed of the Otootan variety of soybeans, selected for uniformity of size and shape, were sterilized in a 1-1,000 mercuric bichloride solution for 15 minutes, then completely washed in distilled water and finally sown in purified quartz sand in wooden boxes. The sand was previously flooded with distilled water and then flushed with the basic nutrient solution to be used in the experiment, but diluted to one-third concentration. Traces of minor elements were added, except boron and manganese. Seed germination was good enough and by the fifth day after sowing relatively uniform seedlings were produced. The best were selected and transferred to purified quartz sand in pots heavily coated with paraffin. Before the seedlings were transplanted, the sand was flushed with distilled water and then supplied with the same dilute basic nutrient solution as was supplied to the seedlings in the sand germinators.

The seedlings were maintained on the dilute nutrient solution, which in addition to the usual minor elements, contained 0.25 p.p.m. of boron and manganese for a period of 1 week. At the end of this period all plants appeared healthy and rigorous and the boron-manganese nutrient treatments

${ }^{1}$ Associate Horticulturist and Associate Soil Scientist, respectively, Agricultural Experiment Station, University of P'uerto Rico, Río l'iedras, P. R.

2 Italic numbers in parentheses refer to Jiterature Cited, p. 34. 
were started. A slightly modified four-salt solution used by Shive in boron studies was used in this study. The composition of the nutrient solution was as follows, in mols: $\mathrm{KH}_{2} \mathrm{PO}_{4}, 0.0020 ; \mathrm{NaNO}_{3}, 0.0038 ; \mathrm{MgSO}_{4}, 0.0028$; $\mathrm{CaCl}_{2}, 0.0020$; with iron and zinc added in quantities equivalent to 1.0 and 0.25 p.p.m., respectively. Five boron levels were used: $0,0.005,0.5,3$, and 5 p.p.m. Six manganese concentrations were employed at each boron

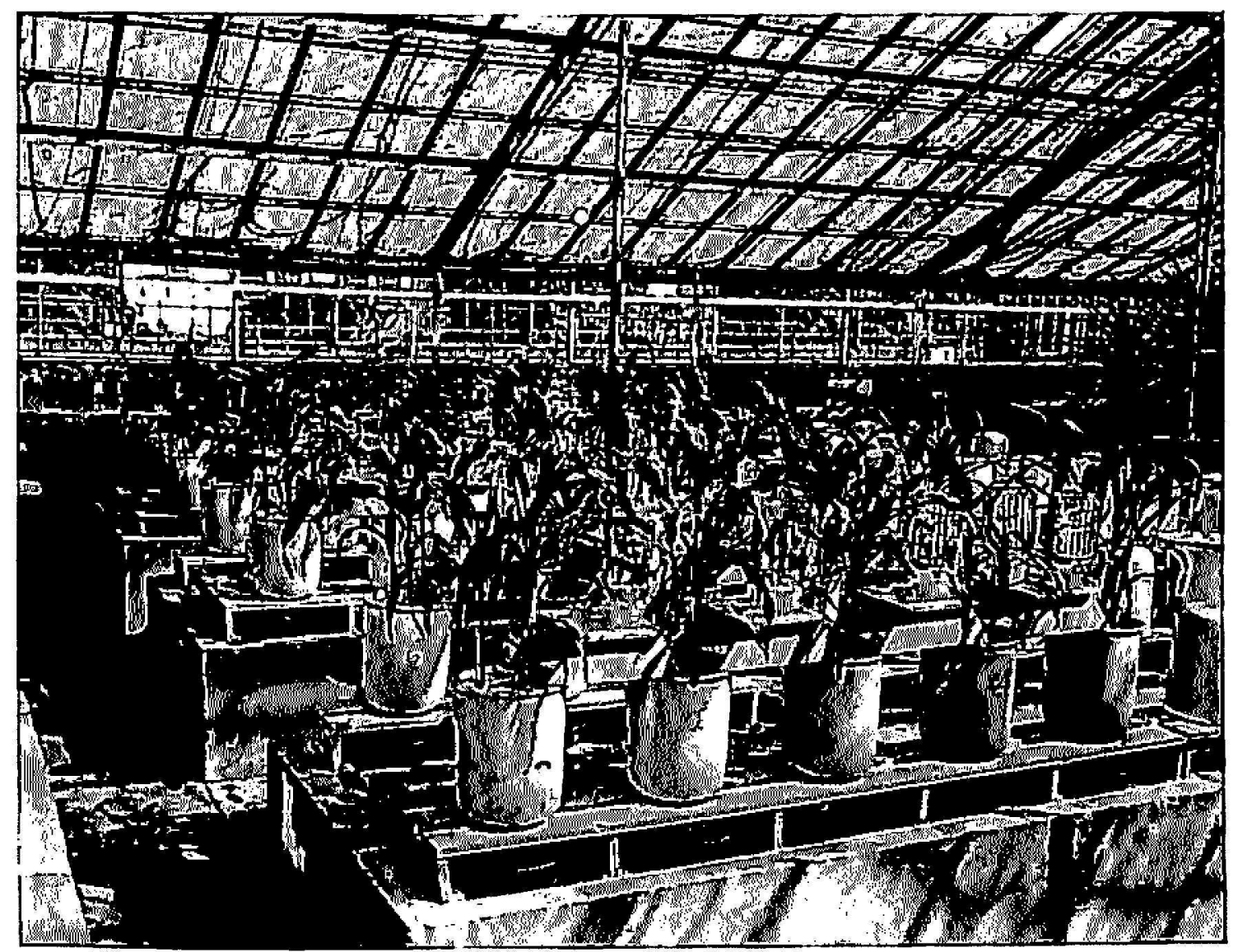

Fig. 1.-General view of the corn experiment.

level: $0,0.001,0.01,0.25,2$, and 5 p.p.m., making a total of 30 treatments. Three plants were used in each culture.

\section{CORN EXPERIMENT}

The experiment with Mayorbela corn (fig. 1) was carried out on the same general pattern as the one just described, with the differences mentioned below. The seed were germinated in acid-alkaline washed quartz sand in wooden germinators. There were 25 cultures divided into groups of 5 , each at a different boron level as follows: 0, 0.01, 0.25, 2, and 5 p.p.m. Manganese was used at the same levels as was boron. The continuous renewal method of Shive and Stahl (6) was used in supplying the various nutrient solutions. The experiment was harvested about 1 month after 
setting the treatment differentials. Data on green and dry weight of plants were recorded and the top leaves were sectioned for chemical analyses.

\section{A.NALYTICAL METHODS}

The procedure for taking the leaf samples and preparing them for chemical analyses was similar to that reported in calcium-boron studies with corn (2), except that for manganese determinations the corresponding aliquot portion was evaporated to dryness on a hot plate to remove excess hydrochloric acid.

The quinalizarin method of Berger and Truog was used for boron determinations (1). Manganese was determined according to the Saywell and Cunningham orthophenanthroline method using a Coleman spectrophotometer (4).

\section{RESULTS AND DISCUSSION}

TOXICITY SYMPTOMS IN SOYBEANS

One month after treatments began, soybean plants at the $0-, 0.001-$, and 0.01-p.p.m. manganese levels showed better growth with less chlorosis as the boron concentration increased up to 0.5 p.p.m.

At 0 boron, increments of manganese in the substrate up to 2 p.p.m. produced better plant growth with less chlorosis. Five parts per million of manganese in the nutrient solution was definitely toxic to the plants, but the toxicity was lessened and better growth obtained with increasing concentrations of boron up to 0.5 p.p.m.

Plants receiving 0.5 p.p.m. of boron developed some necrotic spots on the lower leaves, hence this concentration appeared to be somewhat harmful. Concentrations of boron higher than this ( 3 and 5 p.p.m.) were definitely toxic with the appearance of necrotic spots along the leaf margins and chlorosis of the older leaves.

\section{EFFECT OF TREATMENTS ON DRY WEIGHT OF BEANS}

Table 1 presents the dry weight of beans harvested (beans plus pods). With boron absent from the substrate the maximum yield was obtained with 2 p.p.m. of manganese. With manganese absent the maximum yield wats obtained with 0.5 p.p.m. of boron.

At the highest level of manganese (5 p.p.m.) yields were heaviest on plants which received intermediate quantities of boron rather than on those grown without boron, or at the two highest boron levels. This is in agreement with the previous observations made on the plants in which manganese toxicity at 5 p.p.m. was lessened and better growth obtained with increments of boron up to 0.5 p.p.m. Thus it seems that, at relatively 
high concentrations of manganese in a substrate still capable of producing toxicity in plants, boron tends to prevent the detrimental effect of excess manganese on plant growth.

\section{TOXICITY SYMPTOMS IN CORN}

During the course of the experiment no definite symptoms were observed in the corn plants which could be attributed to deficient manganese in the substrate. However, slight apparent manganese toxicity developed at the two highest manganese levels (2 and 5 p.p.m.) and at the four lowest boron levels. The toxicity symptoms were characterized by the appearance of round or rectangular yellow spots, especially at the edges of leaves and extending toward the midrib or central vein. Boron-toxicity symptoms were slight in the plants at the 2-p.p.m. boron level, but were more no-

TABLE 1.-Dry weight of soybeans (beans and pods) from plants grown in sand cullures at different boron and manganese levels

\begin{tabular}{c|c|c|c|c|c|c}
\hline \multirow{2}{*}{ Boron level (p.p.m.) } & \multicolumn{7}{|c|}{ Yields at indicated manganese levels (p.p.m.) } \\
\cline { 2 - 7 } & 0 & 0.001 & 0.01 & 0.25 & 2.0 & 5.0 \\
\hline & Grams & Grams & Grams & Grams & Grams & Grams \\
& 25 & 33 & 39 & 42 & 43 & 23 \\
.005 & 34 & 38 & $3-1$ & 45 & 27 & 32 \\
.5 & 44 & 33 & 43 & 33 & 44 & 31 \\
3.0 & 26 & 31 & 35 & 32 & 27 & 26 \\
5.0 & 22 & 21 & 16 & 21 & 19 & 13 \\
\hline
\end{tabular}

ticeable in those at the 5-p.p.m. level (fig. 2). Boron-toxicity symptoms were manifested by a rather pale yellow-green color of the younger leaves and brown, dead margins and tips of the older or lower leaves. In addition, the plants were rather stunted in growth.

\section{CHEMICAL ANALYSES OF CORN LEAVES}

The results of the quantitative analyses for total and soluble boron, manganese, and iron contents of the top leaves of the corn plants are presented in table 2 . It can be seen that both total and soluble boron contents are mainly determined by the boron roncentration of the substrate and are largely independent of the nutrient concentration of manganese, except at the highest level of boron where total and soluble boron of the plant tissue were modified to some extent by the manganese concentrations. However, the modifications were not consistent enough to warrant a definite conclusion.

Total- and soluble-manganese contents at any given manganese level, 
except the highest, were more or less independent of the boron level. At the highest manganese level (5 p.p.m.) there was a considerable reduction of both total and soluble manganese in the leaves of the corn plants as the

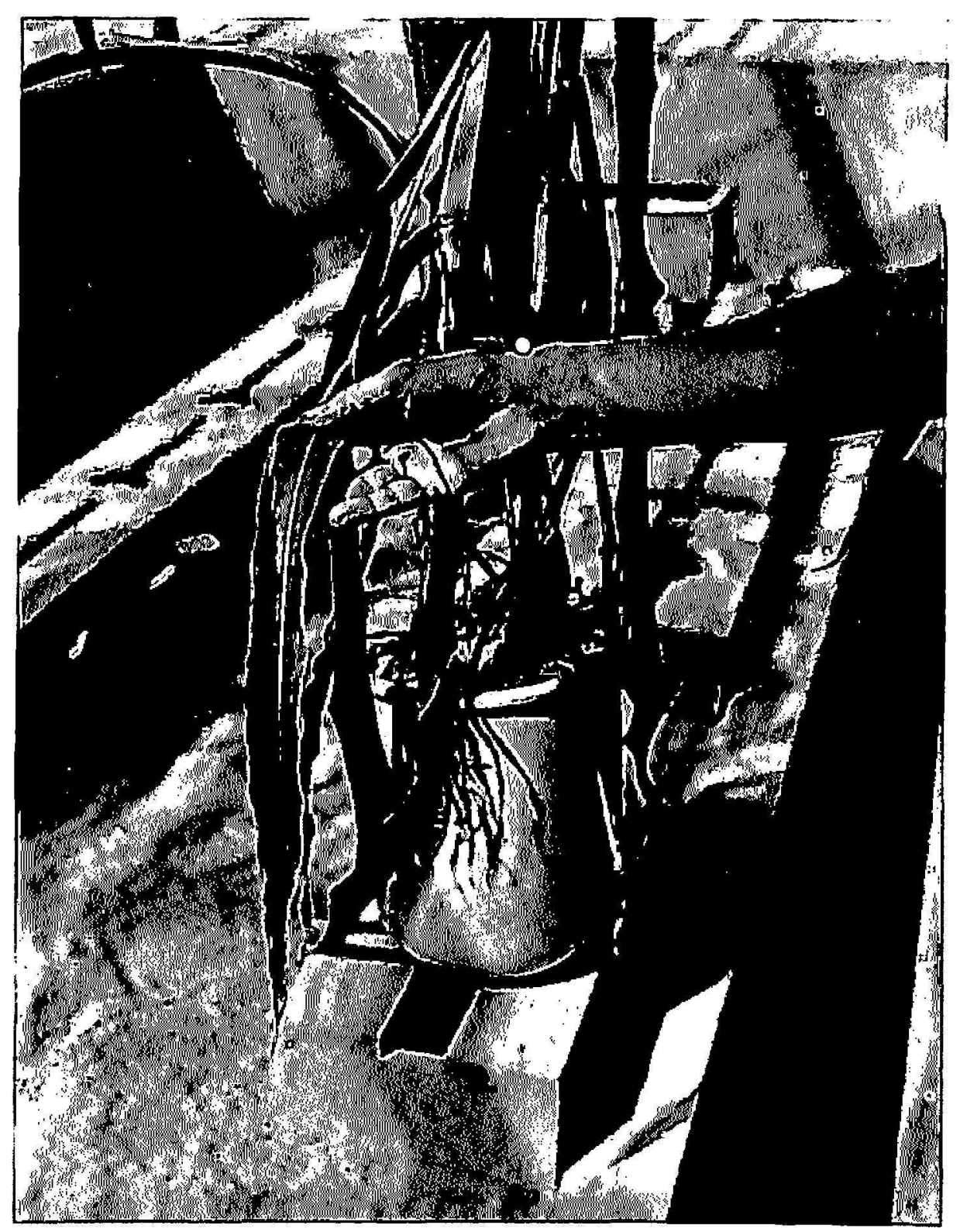

FIt. 2.-Corn leaf showing boron-toxicity symptoms from plants grown at a nutrient level of 5 p.p.m. boron.

boron level increased. This suggests that manganese accumulation by the plant was modified in some way as the boron concentration increased.

Although in this work no manganese determinations were made on the lower and middle leaves of plants showing toxic effects owing to a high manganese level, the fact that the apparent manganese-toxicity symptoms in the plants decreased with increments of boron in the substrate points to the possibility that boron might have acted similarly in modifying the 
TaвLE 2.-Total and soluble boron, manganese, and iron of top leaves of corn plants grown at different levels of boron and manganese

\begin{tabular}{|c|c|c|c|c|c|c|c|c|}
\hline \multirow{2}{*}{ Culture No. } & \multicolumn{2}{|c|}{ Treatments } & \multirow{2}{*}{$\underset{B}{\text { Total }}$} & \multirow{2}{*}{$\underset{B}{\text { Soluble }}$} & \multirow{2}{*}{$\begin{array}{l}\text { Total } \\
\text { Mln }\end{array}$} & \multirow{2}{*}{$\begin{array}{l}\text { Soluble } \\
\text { Mn }\end{array}$} & \multirow{2}{*}{$\underset{\text { Total }}{\text { Fe }}$} & \multirow{2}{*}{ 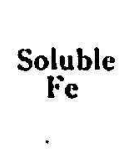 } \\
\hline & B & Min & & & & & & \\
\hline & P.p.m. & P.p.m. & P.p.m. & P.p.m. & P.p.m. & P.p.m. & P.p.m. & P.p.m. \\
\hline 1 & 0 & 0 & 20.0 & 14.2 & 18.00 & 8.73 & 162.50 & 04.44 \\
\hline 2 & 0 & .01 & 25.0 & 17.8 & 14.00 & 5.98 & 83.75 & 18.97 \\
\hline 3 & 0 & .25 & 25.0 & 18.2 & 50.00 & 28.32 & 68.75 & $25.3 !$ \\
\hline 4 & 0 & 2.0 & 25.0 & 15.5 & 186.00 & $7 \bar{t} .62$ & 96.25 & 74.97 \\
\hline 5 & 0 & 5.0 & 25.0 & 18.7 & 796.00 & 724.76 & 102.50 & 27.64 \\
\hline 6 & .01 & 0 & 20.0 & 10.0 & 16.00 & 7.97 & 70.25 & 18.28 \\
\hline 7 & .01 & .01 & 25.0 & 13.3 & 14.00 & 1.28 & 75.00 & 32.76 \\
\hline 8 & .01 & .25 & 25.0 & 18.8 & 58.00 & 40.75 & 90.00 & 37.63 \\
\hline 9 & .01 & 2.0 & 25.0 & 20.1 & 150.00 & 80.27 & 85.00 & 29.65 \\
\hline 10 & .01 & 5.0 & 25.0 & 15.7 & 275.00 & 160.37 & 85.00 & 29.41 \\
\hline 11 & .25 & 0 & 35.0 & 24.0 & 22.00 & 14.66 & 93.75 & 51.25 \\
\hline 12 & .25 & .01 & 45.0 & 31.5 & 22.00 & 11.22 & 90.00 & 58.19 \\
\hline 13 & .25 & .25 & 40.0 & 29.3 & 50.00 & 28.59 & 93.75 & 50.24 \\
\hline 14 & .25 & 2.0 & 35.0 & 20.7 & 167.00 & 122.07 & 105.00 & 65.66 \\
\hline 15 & .25 & 5.0 & 25.0 & 7.0 & 169.00 & 49.49 & 112.50 & 30.07 \\
\hline 16 & 2.0 & 0 & 62.5 & 40.6 & 20.00 & 8.01 & 70.00 & 22.12 \\
\hline 17 & 2.0 & .01 & 62.5 & 45.1 & 14.00 & 8.16 & 75.00 & 37.47 \\
\hline 18 & 2.0 & .25 & 62.5 & 46.7 & 48.00 & 23.23 & 62.50 & 4.67 \\
\hline 19 & 2.0 & 2.0 & 62.5 & 42.3 & 158.00 & 64.15 & 75.00 & 11.89 \\
\hline 20 & 2.0 & 5.0 & 62.5 & 46.5 & 306.00 & 177.80 & 100.00 & 29.49 \\
\hline 21 & 5.0 & 0 & 312.5 & 275.4 & 14.00 & 3.20 & 58.75 & 4.74 \\
\hline 22 & 5.0 & .01 & 137.5 & 125.5 & 14.00 & 5.28 & 50.00 & 18.07 \\
\hline 23 & 5.0 & .25 & 87.5 & 53.0 & 52.00 & 15.19 & 70.00 & 3.67 \\
\hline 24 & 5.0 & 2.0 & 162.5 & 142.8 & 148.00 & 86.00 & $92 . \approx 0$ & 37.66 \\
\hline 25 & 5.0 & 5.0 & 150.0 & 118.0 & 164.00 & 92.90 & 85.00 & 9.61 \\
\hline
\end{tabular}

TABIE 3.-Dry weighl of corn (tops and rools) grown on sand cullure at differenl boron. and manganese levels

\begin{tabular}{c|c|c|c|c|c|c}
\hline \multirow{2}{*}{ Boron level (p.p.m.) } & \multicolumn{6}{|c|}{ Yields at indicated manganese levels (p.p.m.) } \\
\cline { 2 - 7 } & 0 & 0.01 & 0.25 & 2.0 & 5.0 & Average \\
\hline & Grams & Grams & Grams & Grams & Grams & Grams \\
& 103 & 84 & 110 & 68 & 102 & 93 \\
.01 & 95 & 82 & 91 & 101 & 115 & 97 \\
.25 & 107 & 62 & 100 & 95 & 101 & 93 \\
2.0 & 74 & 80 & 82 & 82 & 100 & 84 \\
5.0 & 80 & 66 & 62 & 40 & 35 & 57 \\
\hline Average & 92 & 75 & 89 & 77 & 91 & \\
\hline
\end{tabular}


accumulation of manganese in the lower or middle leaves, as was the case in the top leaves of the corn plants.

EFFECT OF TREATMLNTS ON DRY WEIGHT OF CORN

Table 3 presents data on the dry weight of both corn tops and roots. Manganese levels such as were used in the nutrient medium did not adversely affect the corn plants. However, boron concentrations of 2 p.p.m. and, especially of 5 p.p.m., reduced yields, in general.

\section{SUMMARY}

The possibilities of ameliorating manganese-induced chlorosis with boron applications were studied under greenhruse conditions using soybean and corn as indicator plants. Five levels of boron with six manganese concentrations were used in the soybean experiment. Boron and manganese were used at five levels each in the corn experiment. Observations were made as to the development of toxicity symptoms. Boron, manganese, and iron were determined in the top leaves of the corn plants. Measurements of dry-matter production were made for both crops. Five parts per million of manganese was toxic to soybean plants and reduced yields, but toxicity was lessened by increasing the boron in the nutrient solution up to $0 . \overline{5}$ p.p.m. Boron was toxic also at levels above 0.5 p.p.m.

No definite manganese-toxicity symptoms developed in the corn plants. In general, high boron $(2,5$ p.p.m.) reduced corn yields regardless of the manganese level.

Chemical analyses of the corn leaves suggests the possibility that manganese accumulation may be modified to some extent by boron concentrations.

\section{RESUMEN}

Se estudiaron bajo condiciones de invernadero las posibilidades de aliviar la clorosis inducida por manganeso con el uso de boro. Las plantas indicadoras fucron las habichuelas soyas y el maíz. En cl experimento con habichuelas soyas se usaron cinco niveles de boro y seis de manganeso, mientras que en el de maíz ambos elementos se aplicaron en cinco conrentraciones distintas. Se hicieron determinaciones de boro, manganeso y hierro en las hojas de maíz. Se observaron los síntomas de toxicidad y se midieron los rendimientos de materia seca en ambas cosechas. Cna concentración de 5 p.p.m. de manganeso resultó tóxica para la habichuela soya reduciendo la producción de materia seca, pero la toxicidad se alivió ron aplicaciones de boro hasta 0.5 p.p.m. Concentraciones de boro mayores de 0.5 p.p.m. resultaron tóxicass también.

No se observaron síntomas definidos de toxicidad atribúbles al manga- 
neso en el caso del maíz. Niveles altos (2,5 p.p.m.) de boro afectaron adversamente los rendimientos de máz en casi todos los niveles de manganeso.

Los resultados de los análisis químicos de las hojas de maíz sugieren la posibilidad de que las acumulaciones de manganeso sean modificadas, dentro de ciertos límites, por las concentraciones de boro en el substrato.

\section{LITERATURE CITED}

1. Berger, K. C., and Truog, E., Boron determination in soils and plants using the quinalizarin reaction, Ind. Eng. Chem., Anal. Ed. 11 540-45, 1939.

2. Hernández-Medina, E., and Shive, J. W., Calcium-boron relationship in the nutrition of corn and the distribution of these elements in the plant, $J$. A $f r$. Univ. P. R. 30 (4) 251-91, 1946.

3. Hopkins, F. F., Pagán, V., and Ramírez-Silva, F. J., Iron and manganese in relation to plant growth and its importance in Puerto Rico, J. Agr. Univ. P. R. 28 (2) 43-101, 1944.

4. Saywell, I. G., and Cunningham, 13. 13., Determination of iron-colorimetric ophenanthroline method, Ind. Eng. Chem., 9 67-9, 1937.

5. Schapelle, N. A., The effect of $\mathrm{pH}$ and of certain minor elements on the growth of pineapples in water cultures, $J . A g r$. Univ. P.R. 26 (3) 63-72, 1942.

6. Shive, J. W., and Stahl, A. L., Constant rate of continuous solution renewal for plants in water cultures, Bol. Gaz. 84 317-23, 1927. 